\title{
STUDY OF RAPPORT OF THE MILK POLLUTION BY MULTIDRUG-RESISTANT BACTERIA ('SUPERBUGS'), COWS MORBIDITY AND CALVES LETHALITY IN HOLDINGS OF EASTERN UKRAINE
}

\author{
Kolchyk O. V., Korneikov O. M., Bobrovytska I. A. \\ National Scientific Center 'Institute of Experimental and Clinical Veterinary Medicine', \\ Kharkiv, Ukraine, e-mail: kolchyk-elena@ukr.net
}

\begin{abstract}
Summary. Pasteurella multocida (46.0\%), Neisseria spp. (44.0\%), Aspergillus fumigatus (10.0\%) were isolated in stable consortia form from milk samples $(\mathrm{n}=60)$ from cows in 6 herds $(\mathrm{n}=627$ heads) with clinical signs of immunodeficiency status. The bacteria of these consortia is strong resistant to lots of antibiotics from synthetic penicillin group (ampiox, amoxiclav, ampicillinum), cephalosporins (cefalexin, cefixime), and macrolides (macropene, tylosin). The etiological structure of bacterial infections in cattle and their calves $(n=57)$ in mentioned farm holdings of eastern Ukraine was determined (6 farms in 3 regions). In the majority of these livestock, respiratory syndrome has been recorded for a long time in $56.0 \%$ of calves from 20 days to 5 months old. The signs of diarrhea were revealed in $12.0 \%$ of lactating and dry cows of these livestock, $18.0 \%$ of these animals showed the clinical manifestation of mastitis and $9.0 \%$ of them had the diarrhea syndrome. Pasteurella multocida (48.0\%), Mycoplasma bovis (32.0\%), Neisseria spp. (12.0\%), Clostridium perfringens (8.0\%) were identified using microbiological methods from nasal and rectal swabs from calves of different age groups, from cows with clinical signs of mastitis were isolated Mycoplasma bovis (50.0\%), Pasteurella multocida (34.0\%), Neisseria spp. (16.0\%). Pasteurella multocida, Neisseria spp. and Clostridium perfringens isolates showed strong resistance to ampiox, amoxiclav, ampicillinum, cefalexin, cefixime, macropene, and tylosin. It was concluded that mentioned multidrug-resistant animal infectious agents in human food chain could be a sources of antibiotic resistance genes for human pathogens.
\end{abstract}

Keywords: antimicrobial drugs, bacterial infections, mastitis, microbiological methods, respiratory syndrome, resistance

Introduction. Industrial technology for the production, growing and fattening of young cattle is associated with a high concentration of animals of the same age in confined areas, which contributes to the emergence of epizootic and enzootic diseases.

Bovine pneumoenteritis is the most common diseases, which is widespread among calves and causes large economic losses. Its etiological agents are viruses belonging to the families of Herpesviruses (the virus of infectious bovine rhinotracheitis), Paramyxoviruses (parainfluenza virus-3 and respiratory syncytial virus), Pestiviruses (bovine viral diarrhea-mucosal disease virus), Adenoviruses, etc. Young animals are especially seriously ill when two or more pathogens are involved in the pathological process. There are no clinical signs in animals with normal functioning immune system (Sidorenko, 1998).

In severe course of viral infection, along with the affection of sensitive cells, there is a significant inhibition of the both cellular and humoral parts of immune system, resulting in activation of conditionally pathogenic microflora (Pasteurella, Mycoplasma, Neisseria, Clostridium) and in developing of infectious process, which leads to a significant withdrawal of diseased animals and lowering their productivity (Bennett, 2008).

The bovine pneumoenteritis in calves is obligatory associated with morbidity of cows on mastitis and endometritis which are important items of the bovine pathology. The last significantly reduces the efficiency of the animals using, and it affects the economy of dairy and cattle breeding. Important role in the mastitis and endometritis pathogenesis complication plays infectious rhinotracheitis and viral diarrhea agents, when their consortia with Pasteurellaspp., Mycoplasma spp., Neisseria spp., Clostridium spp., Candida spp. and/or Aspergillus spp. are formed (Demain and Sanchez, 2009).

The knowledge in etiology of the bovine pneumoenteritis and dairy cow's mastitis/endometritis and especially in antibiotic resistance of their agents is crucial for control measures development in veterinary aspects. However, it has great significance also in 'OneHealth' programs aspects for control of antibiotic contamination of human food chains.

The purpose of research. To study the etiological structure of the mentioned diseases of calves and cows in farms and their relation with multidrug-resistant microflora in drinking milk in eastern Ukraine.

Materials and methods. Eighty samples of blood serum from calves, 57 samples of pathological material from dead calves (from 20 days to 6 months), 36 swabs from the rectum, 28 swabs from the nasal cavity, 50 samples of milk from cows with mastitis, and 67 vaginal swabs were used for the studies. Samples were obtained from calves with pneumoenteritis and cows with clinical signs of endometritis and mastitis in 6 farms of 3 Ukrainian regions in 2016-2017. 
As it is prescribed by Standard operating procedures of National Scientific Center 'Institute of Experimental and Clinical Veterinary Medicine' (SOP NSC 'IECVM'), bacterial pathogens were isolated in form of bacterial associations/consortia as result of clinical studies (during sampling of nasopharyngeal and rectal erosion, blood or blood serum collection) and pathological investigations of dead calves were conducted (Golovko, 2007). The study of cultural and morphological properties of the separate bacteria strains were conducted using 'HiMedia' and 'Oxoid' bacteriological nutrient media listed below: meatpeptone broth with the addition of $1.0 \%$ glucose (MPB), $2.5 \%$ meat-peptone agar with $1.0 \%$ glucose (MPA), Endo agar, Olkenitsky nutrient medium, Simon's citrate agar, Muller's medium, Ploskirev's medium with synthomycinum, Bismuth-sulfite agar, PPLO selective media for Mycoplasma (modified Edward medium), wheat-yeast agar with the addition of $10.0 \%$ of milk serum, Hottinger broth and Hottinger nutrient agar, Sabouraud dextrose agar for fungi species isolation, Thioglycollate broth (USP Alternative) for anaerobic species isolation. The hemolytic properties of the separate bacterial isolates were studied during cultivation on MPA with the addition of $0.5 \%$ of the defibrinated sheep blood.

The pathogenicity of all isolated and identified bovine bacterial agents was evaluated by classical bioassays test on nonlinear white mice weighing $18-20 \mathrm{~g}$. Antibiotic susceptibility of isolated bacterial isolates was determined by the routine disc diffusion test.

The appropriate field samples were investigated by standard virological methods as prescribed by the SOP NSC 'IECVM'.

The evaluation of the diseased calves and cows functional state was carried out by the assays of traditional clinical and biochemical parameters in their blood according to standardized methods (Samarina, 2002).

Results and discussion. Data of an epizootological survey of livestock farms and a clinical examination of cattle and progeny showed that calves pneumoenteritis is recorded in all studied Ukrainian regions.

Twin peaks of the disease incidence of calves was recorded in the winter-spring and summer periods, which is due to the massive calving of the cows (congestion), the birth of the weakened calves, with reduced resistance and bad adaptive ability. In summer, the infection was detected among 4-6 month old animals, which got sick during the winter and spring period, that is, recurrence of the chronic diseases were detected.

Associative viral-bacterial infections which manifested as pneumoenteritis in calves, dairy cow mastitis, endometritis and winter diarrhea were widespread in the structure of animal's morbidity and death on 6 studied farms (Table 1).

All studied bovine herds $(n=6)$ had the immunodeficiency status according to results of biochemical blood analysis.
Table $1-$ The bovine morbidity and lethality structure $(\mathrm{n}=627)$

\begin{tabular}{|c|l|c|c|}
\hline Stage & Bovine ages / group & Morbidity, \% & Lethality, \% \\
\hline 1 & $\begin{array}{l}\text { Calves to 20 days age, } \\
\mathrm{n}=73\end{array}$ & $27.0-39.0$ & $21.0-33.0$ \\
\hline 2 & $\begin{array}{l}\text { Calves to 2 month age, } \\
\mathrm{n}=148\end{array}$ & $18.0-42.0$ & $14.0-28.0$ \\
\hline 3 & $\begin{array}{l}\text { Calves to 3-6 month } \\
\text { age, } \mathrm{n}=86\end{array}$ & $31.0-56.0$ & $10.0-24.0$ \\
\hline 4 & $\begin{array}{l}\text { Lactating cows with } \\
\text { clinical manifestation } \\
\text { of mastitis, } \mathrm{n}=51\end{array}$ & $14.0-18.0$ & - \\
\hline 5 & $\begin{array}{l}\text { Post-partum cows } \\
\text { with clinical } \\
\text { manifestation of } \\
\text { endometritis, } \mathrm{n}=22\end{array}$ & 12.0 & - \\
\hline 6 & $\begin{array}{l}\text { Dry and lactating cows } \\
\text { with clinical signs of } \\
\text { winter diarrhea', } \mathrm{n}=18\end{array}$ & 8.0 & 1.0 \\
\hline
\end{tabular}

The structure of etiological microflora of the bovine morbidity-mortality in 6 studied agro holdings is presented at Table 2.

Table 2 - The associative bovine bacterial infections structure

\begin{tabular}{|c|c|c|}
\hline Stage & \begin{tabular}{|c|} 
Bovine ages / \\
group, samples
\end{tabular} & $\begin{array}{l}\text { Bacterial agents } \\
\text { proportions, \% }\end{array}$ \\
\hline 1 & $\begin{array}{l}\text { Calves to } \\
2 \text { month age } \\
(\mathrm{n}=34)\end{array}$ & $\begin{array}{l}\text { Pasteurella multocida }-45.0 \% \\
\text { Mycoplasma bovis }-28.0 \% \\
\text { Neisseria spp. }-17.0 \% ; \\
\text { Clostridium perfringens }-10.0 \%\end{array}$ \\
\hline 2 & $\begin{array}{l}\text { Calves to } \\
3-6 \text { month age } \\
(\mathrm{n}=17)\end{array}$ & $\begin{array}{l}\text { Pasteurella multocida - 48.0\%; } \\
\text { Mycoplasma bovis - 32.0\%; } \\
\text { Neisseria spp. }-12.0 \% ; \\
\text { Clostridium perfringens }-8.0 \%\end{array}$ \\
\hline 3 & $\begin{array}{l}\text { Lactating cows } \\
\text { with clinical } \\
\text { manifestation of } \\
\text { mastitis }(n=51)\end{array}$ & $\begin{array}{l}\text { Mycoplasma bovis - } 50.0 \% \\
\text { Pasteurella multocida }-34.0 \% \\
\text { Neisseria spp. }-16.0 \%\end{array}$ \\
\hline 4 & $\begin{array}{l}\text { Post-partum } \\
\text { cows with } \\
\text { clinical } \\
\text { manifestation } \\
\text { of endometritis } \\
(\mathrm{n}=27)\end{array}$ & $\begin{array}{l}\text { Pasteurella multocida - 46.0\%; } \\
\text { Neisseria spp. - 44.0\%; } \\
\text { Aspergillus fumigatus - } 10.0 \%\end{array}$ \\
\hline 5 & $\begin{array}{l}\text { Dry and } \\
\text { lactating cows } \\
\text { with clinical } \\
\text { signs of 'winter } \\
\text { diarrhea' }(n=6)\end{array}$ & $\begin{array}{l}\text { Concurrent coronaviral- } \\
\text { enterobacterial microflora }\end{array}$ \\
\hline
\end{tabular}

As microbiological results revealed the leading etiological role in bacterial consortia belongs to the 
Pasteurella multocida (from $45.0 \%$ to $48.0 \%$ ) in association with Mycoplasma bovis (from $28.0 \%$ to $50.0 \%$ ) which has been isolated in 6 surveyed farms from all age groups of cattle. The Neisseria spp., Clostridium perfringens, Aspergillus fumigatus we can accept as opportunistic bacteria which support the existence of a stable association in animals. It should be noted that the proportion of Mycoplasma bovis in bacterial consortia reached up to $50.0 \%$ while Pasteurella multocida with Neisseria spp. were in minority in cows with mastitis. The activation of Aspergillus fumigatus with Pasteurella multocida and Neisseria spp. was observed in cows with endometritis. The sensitivity of the isolated cultures of microorganisms to antibiotics was determined by standard disk diffusion test (DDT) simultaneously with all the bacterial agents forming the bacterial consortia and supporting simultaneous growth on appropriate solid nutrient media.
The analysis of the microorganisms sensitivity to antibiotics determination showed that the highest activity to isolated from dead calves microorganisms (Pasteurella multocida, Mycoplasma bovis, Neisseria spp., Clostridium perfringens) was shown to tetracycline, doxycycline, marbofloxacin, ofloxacin, nitroxolin, lincomycin, spectinomycin, oxytetracycline, sulfadimezin, and trimethoprim.

The bacterial association of Pasteurella multocida, Mycoplasma bovis, Neisseria spp., and Clostridium perfringens showed resistance to antimicrobial drugs of the synthetic penicillin group (ampiox, amoxiclav, ampicillin), cephalosporins (cefalexin, cefixime), and macrolides (macropene, tylosin).

Approximately the same microflora with the same multidrug resistance was isolated from $74.0 \%$ samples of raw milk collected in 6 studied agro holdings (Table 3 ).

Table 3 - Bacterial profile of the raw milk samples from agro holdings in Kharkiv, Poltava, and Sumy regions

\begin{tabular}{|c|c|c|c|c|c|c|c|c|c|}
\hline \multirow{2}{*}{ Stage } & \multicolumn{2}{|c|}{ Raw milk samples } & \multicolumn{3}{|c|}{ Proportion of bacteria in consortia, \% } & \multicolumn{2}{c|}{$\begin{array}{c}\text { Prug-resistance of consortia by circle } \\
\text { diameter in DDT }\end{array}$} \\
\cline { 2 - 10 } to antibiotics, mm
\end{tabular}

Notes: to $13 \mathrm{~mm}$ - the pathogen is not sensitive; $13-18 \mathrm{~mm}$ - moderately sensitive; more than $18 \mathrm{~mm}$ - sensitive to antibiotics; ${ }^{*}$ DDT - disk diffusion test with commercial disk kits.

Data presented in Table 3 proves that bacterial consortia structure in milk samples practically are the same as in swabs from cows and diagnostic samples from calves. The formation of multidrug-resistant microflora ('superbugs') in cattle and milk is a result of wide antibiotic spectrum application for treatment in all studied agro holdings.

Conclusions. 1. Pasteurella multocida (46.0\%), Neisseria spp. (44.0\%), Aspergillus fumigatus (10.0\%) were isolated in stable consortia form in milk samples $(n=60)$ from cows in 6 herds ( $n=627$ heads) with clinical signs of immunodeficiency status. The bacteria of these consortia showed strong resistance to different antibiotics from the synthetic penicillin group (ampiox, amoxiclav, ampicillin), cephalosporins (cefalexin, cefixime) and macrolides (macropene, tylosin).
2. Pasteurella multocida (48.0\%), Mycoplasma bovis (32.0\%), Neisseria spp. (12.0\%), Clostridium perfringens $(8.0 \%)$ were identified using microbiological methods from nasal and rectal swabs from different age groups of calves as well as Mycoplasma bovis (50.0\%), Pasteurella multocida (34.0\%), Neisseria spp. (16.0\%) were isolated from dairy cows with mastitis. Pasteurella multocida, Neisseria spp. and Clostridium perfringens isolates exhibited strong resistance to ampiox, amoxiclav, ampicillinum, cefalexin, cefixime, macropene, and tylosin.

3. Application of wide antibiotic spectrum for bovine treatment in all of studied agro holdings causes the formation of multidrug-resistant microflora ('superbugs') in animals and milk from dairy cows. Multidrug-resistant animal infectious agents in human food chain may be sources of antibiotic resistance genes for human pathogens. 


\section{References}

Bennett, P. M. (2008) 'Plasmid encoded antibiotic resistance: acquisition and transfer of antibiotic resistance genes in bacteria: Plasmid-encoded antibiotic resistance', British Journal of Pharmacology, 153(S1), pp. S347-S357. doi: 10.1038/sj.bjp. 0707607.

Demain, A. L. and Sanchez, S. (2009) 'Microbial drug discovery: 80 years of progress', The Journal of Antibiotics, 62(1), pp. 5-16. doi: 10.1038/ja.2008.16.

Golovko, A. N. (ed.) (2007) Microbiological and virological research methods in veterinary medicine: A guide [Mikrobiologicheskie $i$ virusologicheskie metody issledovaniya $v$ veterinarnoy meditsine: Spravochnoe posobie]. Kharkov: NTMT. ISBN 9789668603136. [in Russian].
Samarina, M. N. (2002) Prevention of immunodeficiency within bronchopneumonia in calves by immunostimulants [Profilaktika immunodefitsitov pri bronkhopnevmonii telyat immunostimulyatorami]. The dissertation thesis for the scientific degree of the candidate of veterinary sciences. Ivanovo: Ivanovo State Agricultural Academy. [in Russian].

Sidorenko, S. V. (1998) ‘The clinical significance of microbial resistance to antimicrobial agents' [Klinicheskoe znachenie rezistentnosti mikroorganizmov $\mathrm{k}$ antimikrobnym preparatam], Russian Medical News [Rossiyskie meditsinskie vesti], 1, pp. 2834. [in Russian]. 